\title{
Hip arthroplasty in the very elderly
}

Citation for published version (APA):

Boymans, T. A. E. J. (2017). Hip arthroplasty in the very elderly: anatomical and clinical considerations. [Doctoral Thesis, Maastricht University]. Gildeprint Drukkerijen. https://doi.org/10.26481/dis.20171006tb

Document status and date:

Published: 01/01/2017

DOI:

10.26481/dis.20171006tb

Document Version:

Publisher's PDF, also known as Version of record

\section{Please check the document version of this publication:}

- A submitted manuscript is the version of the article upon submission and before peer-review. There can be important differences between the submitted version and the official published version of record.

People interested in the research are advised to contact the author for the final version of the publication, or visit the DOI to the publisher's website.

- The final author version and the galley proof are versions of the publication after peer review.

- The final published version features the final layout of the paper including the volume, issue and page numbers.

Link to publication

\footnotetext{
General rights rights.

- You may freely distribute the URL identifying the publication in the public portal. please follow below link for the End User Agreement:

www.umlib.nl/taverne-license

Take down policy

If you believe that this document breaches copyright please contact us at:

repository@maastrichtuniversity.nl

providing details and we will investigate your claim.
}

Copyright and moral rights for the publications made accessible in the public portal are retained by the authors and/or other copyright owners and it is a condition of accessing publications that users recognise and abide by the legal requirements associated with these

- Users may download and print one copy of any publication from the public portal for the purpose of private study or research.

- You may not further distribute the material or use it for any profit-making activity or commercial gain

If the publication is distributed under the terms of Article $25 \mathrm{fa}$ of the Dutch Copyright Act, indicated by the "Taverne" license above, 


\section{Summary}

Chapter 1 describes the background and aims of this thesis. It is based on three important aspects. Firstly, several demographical studies indicate that in Western societies the number of very elderly people is growing rapidly due to increased life expectancy. Mainly by that reason, the projected number of hemi and total hip arthroplasties (HHA and THA respectively) performed in this age group is expected to increase as well. Secondly, the morphology of the proximal femur has proven to be ageand gender-related, yet it is unknown whether it continues to change beyond the age of 80 years. Previous investigations regarding this topic mainly consist of analyses on twodimensional X-rays on a much younger population. Thirdly, there is a trend of increased use of cementless implants in hip arthroplasty. At the same time registry data show an increase in implant-related complications such as aseptic loosening and periprosthetic fractures in particular when using cementless implants in the very elderly. This phenomenon is also known as the 'uncemented paradox'. This thesis will study the following questions and aims. It is questioned whether and how the anatomy of the proximal femur in very elderly subjects differs from the 'normal-aged' THA population. The role of stem design and fixation method (either cemented or cementless) on clinical and radiological outcome of hip arthroplasty in the very elderly are investigated. Finally, the parameters used by orthopaedic surgeons to make the decision between a cemented or a cementless fixation of the hip stem are analysed.

Chapter 2 describes a cross-sectional study investigating whether and how the morphology of the proximal femoral canal of subjects aged 80 years and older is different from subjects in the age group most commonly receiving THA. Furthermore, the effect of gender on these potential changes was subject of study. Proximal femoral canal morphology was investigated by measuring coronal and sagittal canal dimensions on 11 levels of high-resolution CT-scans of subjects $\geq 80$ years ( $n=117$; mean age 84.1 years, SD 3.6 years) and subjects $<80$ years $(n=51$; mean age 67.8 years, SD 8.0 years).

The results indicate that the shape and dimensions of the proximal femoral canal indeed differ between subjects below and above the age of 80 years. These 'changes' follow earlier described patterns in younger populations, i.e. canal widening resulting in lower cortical index and stovepipe formation in the coronal plane. These differences between age groups are more profound in females than in males. Beyond the age of 80 years the gender differences present in younger populations seem to diminish leading to a more 'uniform' canal shape in the coronal plane. The transition from a so-called champagne flute shaped to a stovepipe shaped femoral canal does not occur exclusively in the coronal plane, but is in fact more profound in the sagittal plane through preferential loss of cortical bone from the posterior cortex. Furthermore, the changes in 
the coronal plane occur asymmetrically affecting the shape of the endosteal side of the lateral cortex in particular.

Based on this study, the shape of the proximal femoral canal has been identified as an additional factor next to known factors such as osteopenia and stem shape, which might explain why current cementless stem designs result in increased implant-related complications in the very elderly. Current cementless stem designs are namely most of all based on anatomic studies performed on younger populations and focusing on the variety of canal dimensions and shapes solely in the coronal plane.

Chapter 3 aims to investigate whether parameters describing the position of the femoral head differ between very elderly subjects (aged 80 years and older) and middleaged subjects. Three-dimensional femur reconstructions based on high-resolution CTscans of a group of 90 very elderly subjects (mean age 84 years) and a group of 58 middle-aged subjects (mean age 52 years) were used for analysis. The investigated parameters include: the femoral neck-shaft angle (NSA), femoral neck anteversion angle (FNAA), the femoral head height (FHH) and the mediolateral offset (ML-offset). It was found that in the elderly group the femoral neck and head were positioned in a relative varus configuration compared with the younger group. Femoral components with an increased ML-offset and a lower caput-collum-diaphyseal angle might be needed to accommodate the morphology of the femur in very elderly patients. Due to this relative varus configuration of the proximal femur, special care must be taken not to lengthen the operated leg, particularly in very elderly females.

The danger of leg-lengthening and leg-length discrepancy, highlighted in chapter 3, was further investigated in chapter 4 . In the same two populations the correlation between the femoral head diameter (FHD) and the distance between the lesser trochanter and the femoral head center (LT-FHC) was studied. The aim was to determine the accuracy of predicting the position of the femoral head center (FHC) based on the FHD. New age- and gender-specific formulas describing the correlation between FHD and LT-FHC were calculated. Accuracy was assessed on the group of 148 subjects and compared with previously described, more generic, formulas. It was demonstrated that the new age- and gender-specific formulas yield higher accuracy than generic formulas, leading to prediction of the $\mathrm{FHC}$ within $10 \mathrm{~mm}$ of the true value in $95 \%$ of the cases, in contrast with $77 \%$ using previously reported formulas. The new formulas can offer a practical, easy to use instrument for orthopaedic surgeons in addition to classic techniques to prevent significant leg-length discrepancy.

In chapter 5 the influence of stem design on coronal canal fill was investigated in 607 elderly patients ( $\geq 75$ years of age) for three different stem designs: an anatomic, a straight and a combined stem design. Regardless of bone morphotype, classified according to Dorr, the straight stem design offered the most optimal coronal fill pattern 
and the combined stem the least. Main reasons for having a sub- or non-optimal fill were 1) too small dimensions of the stem proximally, and 2) a distal fill that was higher than the proximal fill. The prevalence of early periprosthetic fractures and aseptic loosening did not correlate with stem design in the investigated population. It was concluded that in case a cementless stem intended for proximal metaphyseal load transfer is chosen for the elderly, a straight flat wedge-shaped stem system (preferably offering a large range of sizes) is most likely to deliver an optimal coronal canal fill pattern.

Chapter 6 describes a systematic meta-analysis that investigates which fixation method in hemiarthroplasty of the hip (HHA) (cemented or cementless) yields better scores on mortality, complications, hospital stay, blood loss, duration of surgery and functional results in elderly patients with a femoral neck fracture. Five randomized controlled trials (RCTs) encompassing 950 patients (950 hips) after implantation of current generation hip stems were included and analysed. The main finding was that current generation cementless hip stems result in significantly more complications compared to cemented hip stems. This is in particular true for implant-related complications (odd's ratio 3.15). The conclusion is that in hemiarthroplasty of the hip, current generation cemented stems seem to be a safer option resulting in fewer implant-related complications and similar mortality compared to current generation cementless stems.

Chapter 7 describes a study regarding the parameters that orthopaedic surgeons currently consider for either cemented or cementless stem fixation in primary total hip arthroplasty. A survey regarding current decision making practice was distributed among orthopaedic surgeons specialized in hip arthroplasty. Key topics were: 1) frequency of using cemented / cementless stems; 2) frequency of using parameters which influence the choice between both; 3) usage of specific cut-off values for these parameters. A group of 507 (out of 765) respondents was selected for analysis, because they had at least 5 years experience and performed at least 50 cases a year. Respondents using both fixation techniques (81\%) use a cementless stem in $69 \%$ of the cases. The choice between the two fixation techniques is most frequently based on: 1) patient age; 2) cortical thickness; 3) femoral canal shape; 4) bone mineral density; and 5) stem fit on preoperative templating. The majority (57\%) of respondents using both fixation techniques do not use a specific cut-off value for age. Of the respondents that do use a cut-off value for age $92 \%$ use exclusively cemented stems above a certain age, on average in patients aged $\geq 72.7$ year. Considerable discrepancy and even contradictory responses were present regarding the other parameters and the use of specific cut-off values. The conclusion was that current practice patterns regarding stem fixation in primary THA vary substantially among orthopaedic surgeons. Evidence-based guidelines 
could therefore be needed to define which parameters and threshold values support the best individual choice for hip stem fixation.

In chapter 8 the main findings and clinical relevance of the different aims of this thesis are described in a broader perspective. Recommendations for future research and development are made on each topic. The chapter concludes with some final implications based on the findings described in this thesis, namely the following: 1) cementless stems should be used with caution in the very elderly population seen the changes in canal morphology and the poor fit of cementless implants; 2) in order to optimize reconstruction of the femoral head center in the very elderly, flexibility in mediolateral offset options of femoral components (either cementless or cemented) is demanded. Besides, care must be taken not to lengthen the operated leg in this population; 3) in order to improve the outcome of hip arthroplasty an evidence based algorithm on demographical and bone-related factors could be developed aiding in the choice between cemented or cementless fixation of the hip stem. 
Summary

Samenvatting

Valorisation

PhD portfolio

Dankwoord

Curriculum Vitae 



\section{Samenvatting}

Hoofdstuk 1 beschrijft de achtergrond en doelstellingen van dit proefschrift. Drie aspecten liggen aan dit proefschrift ten grondslag. Ten eerste laten de demografische voorspellingen zien dat in de westerse wereld het aantal mensen op hoge leeftijd toeneemt ten gevolge van een hogere levensverwachting. Mede door die reden, zal naar verwachting het aantal geplaatste hemi- en totale heupprotheses (respectievelijk HHP en THP) dat in deze leeftijdsgroep wordt verricht ook toenemen. Ten tweede is aangetoond dat de morfologie van het proximale femur leeftijds- en geslachtsafhankelijk is. Onderzoek met betrekking tot dit onderwerp omvat met name analyses van tweedimensionale röntgenfoto's van aanzienlijk jongere mensen. Het is echter onbekend of dit proces na de leeftijd van 80 jaar continueert. Ten derde is er een trend dat binnen de heupprothesiologie ongecementeerde implantaten in toenemende mate worden gebruikt ten koste van gecementeerde implantaten. Tegelijkertijd laten data uit implantaat-registers zien dat dit gepaard gaat met een toename van implantaatgerelateerde complicaties zoals aseptische loslating en periprothetische fracturen, met name bij patiënten op hogere leeftijd. Dit fenomeen staat ook wel bekend als de 'ongecementeerde paradox': ondanks de (bekende) complicaties worden er toch meer ongecementeerde implantaten gebruikt. Dit proefschrift is geschreven om de volgende vragen en doelstellingen te onderzoeken. Het is de vraag of bij mensen op hogere leeftijd de anatomie van het proximale femur verschilt met die van mensen met een meer gemiddelde leeftijd waarop een heupprothese wordt geplaatst; en zo ja, hoe dit verschilt. Daarnaast wordt de invloed onderzocht van de fixatiemethode (gecementeerd of ongecementeerd) en van het steelontwerp op de klinische en radiologische resultaten van heupprothesiologie in het algemeen en van ouderen in het bijzonder. Tot slot worden de parameters geanalyseerd die orthopaedisch chirurgen gebruiken om de keuze te maken tussen gecementeerde danwel ongecementeerde fixatie van de heupsteel.

In hoofdstuk 2 wordt een cross-sectionele studie beschreven welke onderzoekt of en hoe de morfologie van het proximale femurkanaal van mensen $\geq 80$ jaar verschilt met mensen in de leeftijdsgroep waarin het vaakst een THP wordt geplaatst. Daarnaast wordt het effect van geslacht op deze potentiële veranderingen onderzocht. De morfologie van het proximale femurkanaal werd onderzocht door het meten van coronale en sagittale dimensies op 11 verschillende niveau's. Hier werden hoogresolutie CT-scans voor gebruikt van mensen $\geq 80$ jaar $(n=117$; gemiddelde leeftijd 84,1 jaar, SD 3,6 jaar) en mensen $<80$ jaar ( $n=51$; gemiddelde leeftijd 67,8 jaar, SD 8,0 jaar).

De resultaten laten zien dat de vorm en afmetingen van het proximale femurkanaal inderdaad verschillen tussen mensen $<80$ en $\geq 80$ jaar. Deze 'veranderingen' volgen eerder beschreven patronen bij jongere populaties, d.w.z. verwijding van het kanaal 
hetgeen resulteert in een lagere corticale index en buisvormig kanaal in het coronale vlak. Deze verschillen tussen leeftijdsgroepen zijn meer uitgesproken bij vrouwen dan bij mannen. Na de leeftijd van 80 jaar lijken de geslachtsverschillen die aanwezig zijn bij jongere populaties minder te worden, hetgeen leidt tot een meer 'uniforme' vorm van het kanaal in het coronale vlak. De transitie van een zogenaamd trechtervormig ('champagne flute') femurkanaal naar een buisvormig ('stovepipe') kanaal treedt niet alleen op in het coronale vlak, maar is zelfs meer uitgesproken in het sagittale vlak, met name door verdunning van de posterieure cortex. Daarnaast is het zo dat de veranderingen in het coronale vlak asymmetrisch optreden, waarbij met name de vorm van de endosteale zijde van de laterale cortex verandert.

Op basis van deze resultaten wordt het proximale femurkanaal gezien als een extra factor, naast bijvoorbeeld osteopenie en steelontwerp, die kan verklaren waarom ongecementeerde stelen leiden tot een toename van implantaatgerelateerde complicaties bij gebruik in patiënten op hogere leeftijd. Het ontwerp van hedendaagse ongecementeerde stelen is namelijk met name gebaseerd op anatomische analyses van jongere populaties die zich louter beperken tot kanaalvorm en -dimensies in het coronale vlak.

Hoofdstuk 3 heeft als doel te onderzoeken of parameters die de positie van de femurkop beschrijven, verschillen tussen mensen op hoge leeftijd ( $\geq 80$ jaar) en mensen van middelbare leeftijd. Drie-dimensionale femur reconstructies op basis van hoogresolutie CT-scans van een groep van 90 ouderen (gemiddelde leeftijd 84 jaar) en een groep van 58 mensen van middelbare leeftijd (gemiddelde leeftijd 52 jaar) werden gebruikt voor analyse. De onderzochte parameters betroffen: de femorale nek-schacht hoek (NSA), de femorale nek anteversie hoek (FNAA), de femurkop hoogte (FHH) en de mediolaterale offset (ML-offset). Uit de resultaten bleek dat bij de oudere groep de femurnek en -kop een relatieve varus positie hadden ten opzichte van de jongere groep. Op basis daarvan zouden heupstelen nodig zijn met een relatief grotere ML-offset en een lagere nek-schacht hoek om het proximale femur van patiënten op hogere leeftijd anatomisch te kunnen reconstrueren. Daarnaast moet er, gezien de relatieve varus configuratie van het proximale femur, op worden gelet dat het te opereren been niet wordt verlengd, in het bijzonder bij vrouwen op hogere leeftijd.

Het risico op beenverlenging en beenlengteverschil, hetgeen werd aangestipt in hoofdstuk 3, werd verder onderzocht in hoofdstuk 4. In dezelfde twee onderzoekspopulaties werd de correlatie tussen de diameter van de femurkop (FHD) en de afstand tussen de kleine trochanter en het centrum van de femurkop (LT-FHC) onderzocht. Het doel was om de nauwkeurigheid te bepalen waarmee de positie van het centrum van de femurkop (FHC) voorspeld kan worden aan de hand van de diameter van de femurkop (FHD). Nieuwe leeftijds- en geslachtsspecifieke formules die de correlatie beschrijven tussen de FHD en de LT-FHC werden berekend. De nauwkeurigheid werd bepaald aan de hand van een groep van 148 mensen en vergeleken met in het verleden beschreven, 
meer generieke formules. Aangetoond werd dat de nieuwe leeftijds- en geslachtsspecifieke formules een hogere nauwkeurigheid bereiken dan de generieke formules, hetgeen ertoe leidt dat de voorspelling van de positie van de FHC binnen $10 \mathrm{~mm}$ van de werkelijke waarde kan plaatsvinden in $95 \%$ van de gevallen, in tegenstelling tot $77 \%$ wanneer de reeds bestaande generieke formules worden gebruikt. De nieuwe formules kunnen een praktisch, eenvoudig te gebruiken instrument vormen voor orthopaedisch chirurgen in aanvulling op klassieke technieken om een significant beenlengteverschil te voorkomen.

In hoofdstuk 5 wordt de invloed van het ontwerp van een heupsteel op de kanaalvulling in het coronale vlak bij 607 oudere patiënten ( $\geq 75$ jaar) onderzocht. Drie verschillende steelontwerpen werden onderzocht: één anatomische, één rechte en één gecombineerd-type steelontwerp. Ongeacht het bot morfotype, geclassificeerd volgens Dorr, bood het rechte steelontwerp het meest optimale coronale kanaalvullingspatroon en het gecombineerd-type steelontwerp het minst. De belangrijkste redenen voor een suboptimaal of niet-optimaal kanaalvullingspatroon waren 1) té smalle afmetingen t.h.v. de proximale zijde van de steel, en 2) een distale kanaalvulling die hoger was dan de proximale kanaalvulling. De prevalenties van vroege periprothetische fracturen en aseptische loslating correleerde niet met steelontwerp in het onderzochte cohort. De conclusie luidde dat indien een ongecementeerde, proximaal metafysair gecoate steel wordt gekozen voor implantatie bij oudere patiënten, een rechte, platte wigvormige steel (met bij voorkeur een grote range aan steelmaten) het meest optimale coronale kanaalvullingspatroon oplevert.

Hoofdstuk 6 beschrijft een systematische meta-analyse met als onderzoeksvraag welke fixatiemethode bij hemiprothesiologie van de heup (HHP) (gecementeerd of ongecementeerd) beter scoort op gebied van mortaliteit, complicaties, opnameduur, bloedverlies, operatieduur en functionele resultaten bij oudere patiënten met een fractuur van het collum femoris. Vijf gerandomiseerd gecontroleerde trials (RCT's) werden geïncludeerd en geanalyseerd. Deze studies onderzochten in totaal 950 patiënten (950 heupen) na plaatsing van louter 'moderne' heupstelen die vandaag de dag frequent worden gebruikt. De belangrijkste bevinding was dat hedendaagse ongecementeerde heupstelen tot meer complicaties leiden dan gecementeerde heupstelen. Dit was met name van toepassing op implantaat-gerelateerde complicaties (odd's ratio 3,15). De conclusie is dat bij HHP de huidige gecementeerde stelen nog steeds een veiligere optie blijken te zijn dan de huidige generatie ongecementeerde stelen, omdat ze resulteren in minder implantaat-gerelateerde complicaties en een vergelijkbare mortaliteit vertonen.

Hoofdstuk 7 heeft als doel te onderzoeken welke parameters orthopaedisch chirurgen momenteel overwegen om te kiezen voor gecementeerde danwel ongecementeerde fixatie van de heupsteel bij primaire totale heupprothesiologie. Een 
enquete met betrekking tot de huidige besluitvorming werd uitgezet onder orthopaedisch chirurgen die gespecialiseerd zijn in heupprothesiologie. De belangrijkste onderwerpen waren: 1) de frequentie waarmee respectievelijk gecementeerde en ongecementeerde stelen worden gebruikt; 2) de frequentie waarmee parameters worden gebruikt die de keuze tussen beide beïnvloeden; 3) het gebruik van specifieke afkapwaardes voor bepaalde parameters. Voor verdere analyse werden van de 765 respondenten alleen de 507 respondenten geselecteerd die tenminste 5 jaar ervaring hadden en ten minste 50 primaire heupprotheses per jaar plaatsten. De respondenten die beide fixatietechnieken toepassen (81\%) gebruiken een ongecementeerde steel in $69 \%$ van de gevallen. De keuze tussen beide fixatietechnieken wordt het meest bepaald aan de hand van: 1) leeftijd van de patiënt; 2) dikte van de cortex; 3) vorm van het femurkanaal; 4) botmineraaldichtheid; en 5) pasvorm van de steel op de pre-operatieve planning. De meerderheid (57\%) van de respondenten die beide technieken gebruikt, gebruikt geen specifieke afkapwaarde voor leeftijd. Van de respondenten die een specifieke afkapwaarde voor leeftijd gebruiken, gebruikt $92 \%$ een bovengrens voor het gebruik van ongecementeerde stelen, namelijk gemiddeld 72.7 jaar. Bij het gebruik van de andere parameters en eventueel specifieke afkapwaardes viel op dat er sprake was van aanzienlijke variabiliteit en zelfs tegenstellingen tussen de respondenten. De conclusie van dit onderzoek was dat momenteel het gebruik van gecementeerde en ongecementeerde steelfixatie bij primaire heupprothesiologie enorm varieert tussen orthopaedisch chirurgen. Evidence-based richtlijnen hieromtrent zouden behulpzaam kunnen zijn om te definiëren welke parameters en afkapwaardes de beste individuele keuze m.b.t. fixatiemethode ondersteunen.

In hoofdstuk 8 worden de belangrijkste bevindingen en klinische relevantie van dit proefschrift in een breder perspectief beschreven. Daarnaast worden per onderwerp aanbevelingen gedaan m.b.t. vervolgonderzoek en ontwikkeling. Het hoofdstuk eindigt met enkele afsluitende adviezen t.b.v. de klinische praktijk gebaseerd op de bevindingen van dit proefschrift, namelijk: 1) ongecementeerde stelen zouden met enige behoedzaamheid moeten worden gebruikt bij patiënten op hoge leeftijd gezien de veranderingen in de vorm van het femurkanaal en de matige pasvorm van ongecementeerde stelen hierin; 2) teneinde het centrum van de femurkop te reconstrueren bij patiënten op hoge leeftijd is enige flexibiliteit wenselijk m.b.t. mediolaterale offset van femurcomponenten (zowel bij ongecementeerde als gecementeerde componenten). Daarnaast moet er voor worden zorggedragen het te opereren been niet te verlengen bij deze populatie; 3) teneinde de resultaten van heupprothesiologie te verbeteren zou een evidence-based algoritme kunnen worden ontwikkeld op basis van demografische en botgerelateerde factoren die de keuze tussen gecementeerde en ongecementeerde fixatie van de heupsteel kunnen vergemakkelijken. 